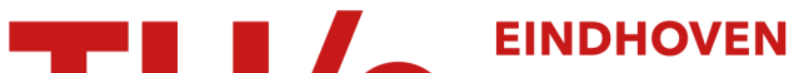

\section{On the photo-oxidation of perylene bisimide dyes in alcoholic solutions}

\section{Citation for published version (APA):}

Lub, J., van Hal, P. A., Smits, R., Malassenet, L., Pikkemaat, J., \& Hikmet, R. A. M. (2019). On the photooxidation of perylene bisimide dyes in alcoholic solutions. Journal of Luminescence, 207, 585-588.

https://doi.org/10.1016/j.jlumin.2018.12.005

DOI:

10.1016/j.jumin.2018.12.005

Document status and date:

Published: 01/03/2019

\section{Document Version:}

Accepted manuscript including changes made at the peer-review stage

\section{Please check the document version of this publication:}

- A submitted manuscript is the version of the article upon submission and before peer-review. There can be important differences between the submitted version and the official published version of record. People interested in the research are advised to contact the author for the final version of the publication, or visit the $\mathrm{DOI}$ to the publisher's website.

- The final author version and the galley proof are versions of the publication after peer review.

- The final published version features the final layout of the paper including the volume, issue and page numbers.

Link to publication

\section{General rights}

Copyright and moral rights for the publications made accessible in the public portal are retained by the authors and/or other copyright owners and it is a condition of accessing publications that users recognise and abide by the legal requirements associated with these rights.

- Users may download and print one copy of any publication from the public portal for the purpose of private study or research.

- You may not further distribute the material or use it for any profit-making activity or commercial gain

- You may freely distribute the URL identifying the publication in the public portal.

If the publication is distributed under the terms of Article 25fa of the Dutch Copyright Act, indicated by the "Taverne" license above, please follow below link for the End User Agreement:

www.tue.nl/taverne

Take down policy

If you believe that this document breaches copyright please contact us at:

openaccess@tue.nl

providing details and we will investigate your claim. 


\section{Author's Accepted Manuscript}

On the photo-oxidation of Perylene bisimide dyes in alcoholic solutions

Johan Lub, Paul A. van Hal, Roel Smits, Lise Malassenet, Jeroen Pikkemaat, Rifat A.M. Hikmet

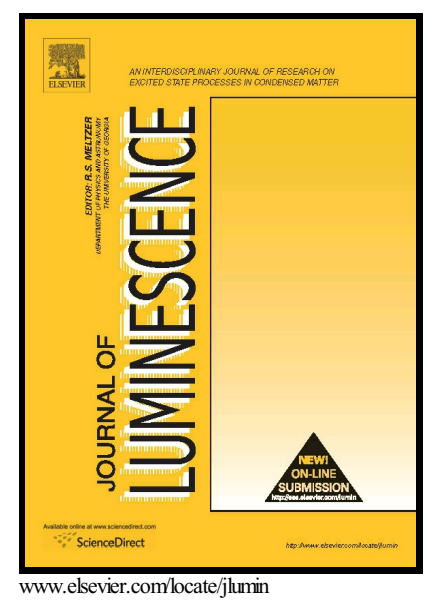

PII: $\quad$ S0022-2313(18)31310-3

DOI: $\quad$ https://doi.org/10.1016/j.jlumin.2018.12.005

Reference: LUMIN16134

To appear in: Journal of Luminescence

Received date: 23 July 2018

Revised date: 22 November 2018

Accepted date: 2 December 2018

Cite this article as: Johan Lub, Paul A. van Hal, Roel Smits, Lise Malassenet, Jeroen Pikkemaat and Rifat A.M. Hikmet, On the photo-oxidation of Perylene bisimide dyes in alcoholic solutions, Journal of Luminescence, https://doi.org/10.1016/j.jlumin.2018.12.005

This is a PDF file of an unedited manuscript that has been accepted for publication. As a service to our customers we are providing this early version of the manuscript. The manuscript will undergo copyediting, typesetting, and review of the resulting galley proof before it is published in its final citable form. Please note that during the production process errors may be discovered which could affect the content, and all legal disclaimers that apply to the journal pertain. 


\section{ACCEPTED MANUSCRIPT}

\section{On the photo-oxidation of Perylene bisimide dyes in alcoholic solutions.}

Johan Lub ${ }^{\mathrm{a}, \mathrm{b},{ }^{*}}$, Paul A. van Hal ${ }^{\mathrm{a}, \mathrm{c}}$, Roel Smits ${ }^{\mathrm{a}, \mathrm{d}}$, Lise Malassenet ${ }^{\mathrm{a}, \mathrm{e}}$, Jeroen Pikkemaat ${ }^{\mathrm{f}, \mathrm{g}}$ and Rifat A.M. Hikmet ${ }^{\mathrm{a}, \mathrm{c}}$.

\section{Abstract.}

Irradiation with intense blue LED light of Lumogen Orange 240 (1) in non-reactive solvents led to bleaching. The products of these photochemical reactions were not possible to determine. Contrarily, irradiation in ethanol or propanol led to red color shifts caused by the formation of the ethoxy or propoxy derivative of Lumogen Orange 240, respectively. These new reaction products of are only formed when both light and oxygen are present. A possible mechanism for these photo-oxidation reactions, the implication for the stability of perylene type of fluorescent dyes under LED lamp conditions and possible preparative applications are discussed.

\section{Keywords}

\section{Lumogen Orange 240}

Photo stability

Photo substitution

Photo-oxidation

Fluorescent compounds

\section{Introduction.}

White LED lamps are made with a layer of color converting dyes on top of the blue LED chip, either directly on the chip or in the more efficient remote phosphor configuration $[1,2]$. In the latter case the more efficient electrical power to light conversion is due to the fact that reflected waves are not absorbed by the LED chip but are able to leave the lighting device without optical losses and thermal quenching. In the remote phosphor configuration more phosphor is needed as a result of the increased surface of the color converting layer [3].

\footnotetext{
a Philips Research, High Tech Campus 34, 5656 AE Eindhoven, The Netherlands

${ }^{\mathrm{b}}$ Present address: Eindhoven University of Technology, P.O. Box 513, 5600 MB, Eindhoven, The Netherlands. * Corresponding author j.lub@tue.nl.

${ }^{c}$ Present address Signify, High Tech Campus 7,5656 AE Eindhoven, The Netherlands

${ }^{d}$ Present address: BDO, Dr. Holtroplaan 15, 5652 XR Eindhoven, The Netherlands.

${ }^{e}$ Present address: Université de Bordeaux, 351 cours de la liberation 33405 Talence, France.

${ }^{f}$ Philips Innovation Services, High Tech Campus 11, 5656 AE Eindhoven, The Netherlands

${ }^{9}$ Present address: Janssen Pharmaceutica, Turnhoutseweg 30, B-2340 Beerse, Belgium.
} 


\section{ACCEPTED MANUSCRIPT}

Inorganic phosphors as the color converter materials are not always preferred due to their price especially in the case of the remote phosphor configuration. Organic phosphors, including derivatives of perylene bisimide, can be a cheap solution for this problem if it wasn't for their relative low stability in comparison to their inorganic counterparts. Several red emitting derivatives of perylene with high quantum efficiency and good photochemical stability can be used for LED lamps [4]. However, the lifetimes of commercially available yellow dyes derived from perylene, that have high quantum efficiencies are much too low for these lighting applications [2,5]. Insufficient photochemical stability of these dyes leads to to early bleaching. For that reason, new yellow emitting dyes were developed that show better lifetimes with preservation of a high quantum efficiency [2,5 6,7]. In order to get more insight in the chemical processes that play a role in the reduced photochemical stability of the perylene derivatives, a study was started to find out which chemical products are formed under intense blue LED irradiation. As a model compound derivative $\mathbf{1}$ is used. This compound with a bisimide perylene core is an orange emissive dye and serves well as a model compound for this photochemical degradation study. The symmetry of the chemical structure of 1 will be very helpful in interpretation of analytical (especially NMR) data of possible reaction products. Although these dyes are applied in polymer films, the study must be performed in solution in order to be able to separate the photo-reaction products needed for chemical analyses. The photo-degradation of $\mathbf{1}$ has been studied in polymethyl methacrylate $[8,9,10,11]$ and in solvents $[12,13]$ without analyzing products formed from 1 . Here, the photo-degradation of $\mathbf{1}$ in solution is studied by attempting to separate its photoreaction products.

\section{Experimental procedure.}

\subsection{Materials}

2,9-bis(2,6-diisopropylphenyl)anthra-[2,1,9-def:6,5,10-d'e'f']diisoquinoline-

1,3,8,10(2H,9H)tetraone (1, commercial number: F240) was a kind gift from Dr. M.

Koenemann of BASF. All other chemicals and solvents were obtained from Sigma-Aldrich.

\subsection{Equipment}

For irradiation a homebuilt lighting device with 12 blue LEDs $(450 \mathrm{~nm})$ was used, driven at $48 \mathrm{~V}$ and $0.9 \mathrm{~A}$, yielding a light intensity of ca $4 \mathrm{~W} / \mathrm{cm}^{2}$ at a distance of $12 \mathrm{~mm} .6 \mathrm{ml}$ samples

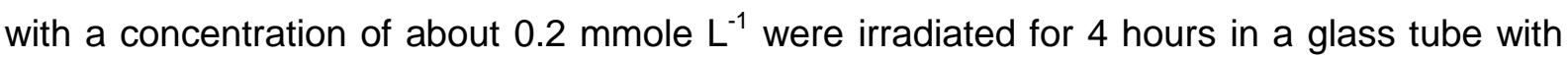
diameter $25 \mathrm{~mm}$ and provided with a magnetic stirrer. The anaerobic experiments were performed with tubes that underwent three freeze-thaw cycles before irradiation. The tubes 
were thermostatted in a water bath at $70^{\circ} \mathrm{C}$ to avoid uncontrolled heating by the LED device. The distance from the vessel wall to the lamp was $12 \mathrm{~mm}$.

Absorption spectra were measured on a Perkin Elmer Lambda $950 \mathrm{UV} / \mathrm{Vis}$ spectrometer. Spectra were recorded after dilution of the samples to a concentration of $0.007 \mathrm{mmol} \mathrm{L}^{-1}$. Luminescence spectra were performed on $0.001 \mathrm{mmol} \mathrm{L}^{-1}$ ethyl acetate solutions with a Perkin-Elmer LS55 fluorescence spectrometer. The emission spectra were measured by excitation at $\lambda(\max )$ of the corresponding excitation spectrum and the excitation spectra were measured by detecting the intensity at $\lambda(\max )$ of the corresponding emission spectrum. LCMS experiments were performed on an Agilent 1200 series Liquid Chromatography system fitted with a, $2.1 \mathrm{~mm}$ ID $\times 100 \mathrm{~mm}$ I $\times 3.5 \mu \mathrm{m}$ dp Eclipse plus C18 column (Agilent). Optical detection was performed using diode array detection and mass spectra were acquired with an Agilent 6210 series TOF-MS using Electrospray Ionisation (ESI) in the positive mode. Preparative LC was performed on a similar system, equipped with a $21.2 \mathrm{~mm}$ IDx150mm I * $5 \mu \mathrm{m}$ dp prep-C18 Zorbax column (Agilent) and a diode array detector.

${ }^{1} \mathrm{H}$ and ${ }^{13} \mathrm{C}$ NMR spectra were measured on samples dissolved in deuterated chloroform using Bruker Avance $300 \mathrm{MHz}$ and $600 \mathrm{MHz}$ NMR spectrometers. All chemical shifts were calibrated relative to TMS, $\delta=0.0 \mathrm{ppm}$.

Two-dimensional (2D) ${ }^{1} \mathrm{H}-{ }^{13} \mathrm{C}$ gradient-enhanced HMBC NMR spectra were acquired at 600 $\mathrm{MHz}$ using the "hmbcgplpndqf" pulse sequence available in the Bruker TOPSPIN 2.1 pulsesequence library $[14,15,16]$. Evolution periods were optimized for the observation of ${ }^{2} \mathrm{~J}_{(\mathrm{CH})}$ and ${ }^{3} \mathrm{~J}_{(\mathrm{CH})}$ coupling constants with a value of approximately $8 \mathrm{~Hz}$. Cross peaks originating from ${ }^{1} \mathrm{~J}_{(\mathrm{CH})}$ coupling constants were adequately suppressed with the use of a low-pass $\mathrm{J}$ filter. No ${ }^{13} \mathrm{C}$ decoupling was used during ${ }^{1} \mathrm{H}$ signal acquisition. As a consequence, residual ${ }^{1} \mathrm{~J}(\mathrm{CH})$ cross peaks could be distinguished from ${ }^{2} \mathrm{~J}_{(\mathrm{CH})}$ and ${ }^{3} \mathrm{~J}_{(\mathrm{CH})}$ cross peaks by the typical splitting of approximately $145 \mathrm{~Hz}$ in the ${ }^{1} \mathrm{H}$ dimension.

Spectral properties of 2,9-bis(2,6-diisopropylphenyl)-5-ethoxyanthra[2,1,9-def:6,5,10d'e'f']diisoquinoline-1,3,8,10(2H,9H)-tetraone (2a): ${ }^{1} \mathrm{H}-\mathrm{NMR}(300 \mathrm{MHz}, \quad \delta$ in ppm, J in Hz): = $9.79(\mathrm{~d}, \mathrm{~J}=8.3,1 \mathrm{H}), 8.81(\mathrm{~d}, \mathrm{~J}=8.0,1 \mathrm{H}), 8.80(\mathrm{~d}, \mathrm{~J}=8.31 \mathrm{H}), 8.79(\mathrm{~d}, \mathrm{~J}=8.1,1 \mathrm{H}), 8.75(\mathrm{~d}$, $\mathrm{J}=8.2,1 \mathrm{H}), 8.71(\mathrm{~d}, \mathrm{~J}=7.9,1 \mathrm{H}), 8.59(\mathrm{~s}, 1 \mathrm{H}), 7.53(\mathrm{t}, \mathrm{J}=7.5,1 \mathrm{H}), 7.52(\mathrm{t}, \mathrm{J}=7.5,1 \mathrm{H}), 7.38(\mathrm{~d}$, $\mathrm{J}=7.5,2 \mathrm{H}), 7.37(\mathrm{~d}, \mathrm{~J}=7.5,2 \mathrm{H}), 4.68(\mathrm{q}, \mathrm{J}=6.9,2 \mathrm{H}), 2.77(\mathrm{~m}, \mathrm{~J}=7.1,2 \mathrm{H}), 2.76(\mathrm{~m}, \mathrm{~J}=7.0,2 \mathrm{H})$, $1.77(\mathrm{t}, \mathrm{J}=6.9,3 \mathrm{H}), 1.20(\mathrm{~d}, \mathrm{~J}=7.0,24 \mathrm{H}) .{ }^{13} \mathrm{C}-\mathrm{NMR}\left(75 \mathrm{MHz}, \delta\right.$ in ppm, *: $\mathrm{CH}, \mathrm{CH}_{2}$ or $\left.\mathrm{CH}_{3}\right)$ : 163.83, 163.65, 163.62, 163.29, 157.97, 145.59, 145.57, 139.19, 135.21, 135.10, 134.52, $132.53^{*}, 131.35^{\star}, 130.59,130.39,129.79,129.72^{*}, 129.63^{*}, 129.54^{*}, 128.85,128.70^{*}$, $127.46,124.91,124.12^{*}, 124.10^{*}, 123.84^{*}, 122.89,122,76,122.23^{*}, 121.69,121.09$, $119.22^{\star}, 66.49^{\star}, 29.70^{\star}, 24.00^{*}, 14.14^{*} . \mathrm{M}+\mathrm{H}=755.35$. UV-Vis: $\lambda_{\max }$ (ethyl acetate) $=551$ 
$\mathrm{nm}, \varepsilon=91500 \mathrm{~L} \mathrm{~mol}^{-1} \mathrm{~cm}^{-1}$ and $526 \mathrm{~nm} \varepsilon=67000 \mathrm{~L} \mathrm{~mol}^{-1} \mathrm{~cm}^{-1}$. Photoluminescence: $\lambda_{\max }$ (ethyl acetate) $=568 \mathrm{~nm}$.

\section{Results and discussion.}

Solutions of 1 in benzene or ethyl acetate were irradiated at $70^{\circ} \mathrm{C}$ for 4 hours. Bleaching of the dye was observed. UV Vis measurements of the solutions during and after irradiation did not give other spectral information than a decrease of the absorption of about $10 \%$. LC-MS experiments with these samples didn't show any new compounds that absorb in the visible region or showed separate peaks in the UV region with well-defined mass. Thus, no conclusion could be obtained of the products that could be formed due to the irradiation. Probably, the degradation products were instable and did not contribute to the absorption spectrum.

If the same irradiation experiments with $\mathbf{1}$ were performed in ethanol or $n$-propanol, the characteristic yellow/orange color of the dye changes to pale red. Formation of a red colored compound after irradiation is also apparent from the absorption spectrum of such a solution; a new peak at $551 \mathrm{~nm}$ arises during irradiation as depicted in Figure 3-1.

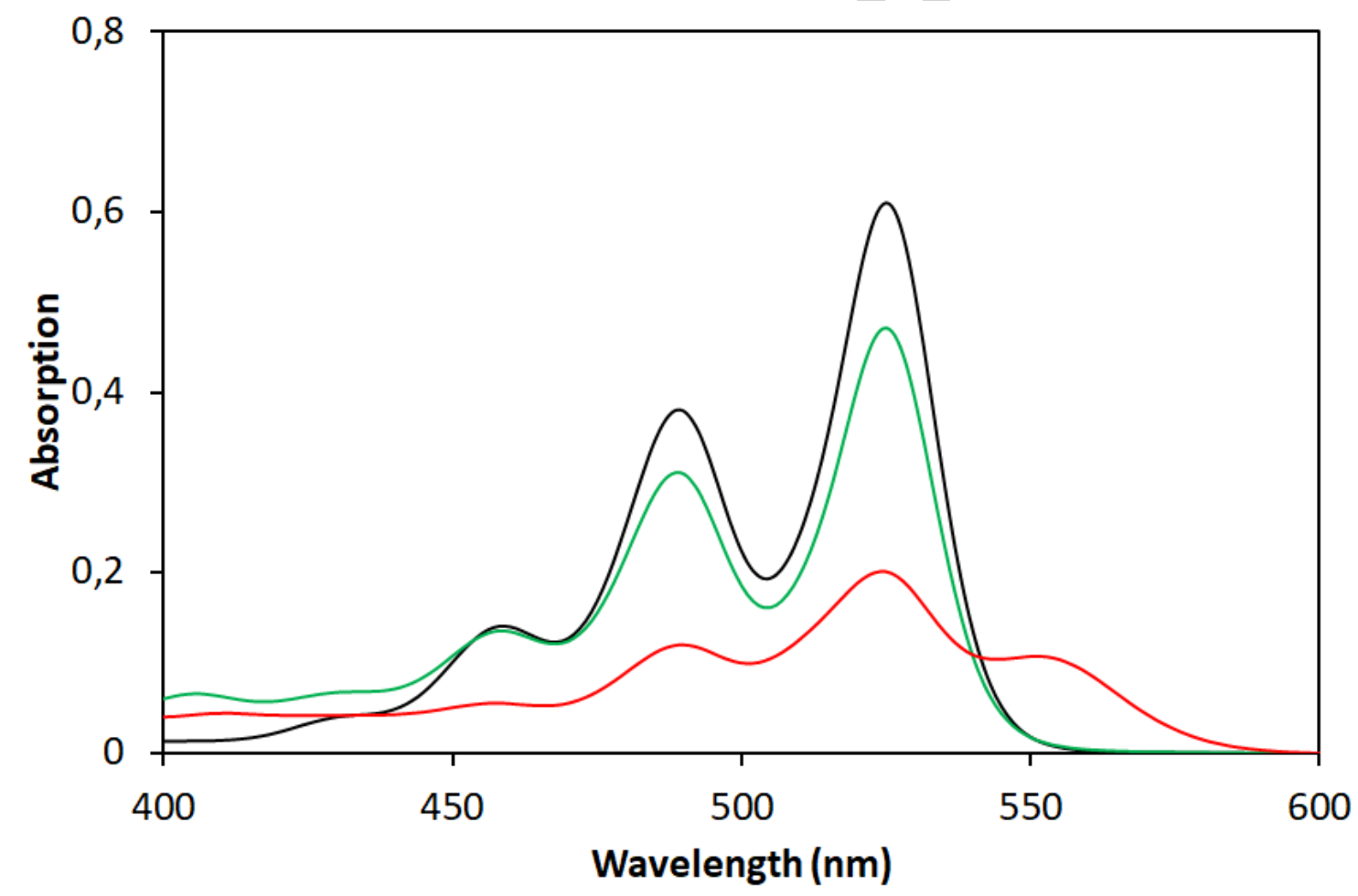

Figure 3-1 UV-Vis spectrum of $\mathbf{1}$ in ethanol before irradiation (black curve), after 4 hours of irradiation under vacuum (green curve) and after 4 hours of irradiation under aerobic conditions (red curve) in ethanol. 
Irradiation of the same sample under vacuum instead of air resulted in a slower decrease of the original spectrum and without formation of the new $551 \mathrm{~nm}$ peak, see also Figure 3-1. Furthermore, an ethanolic solution of dye 1 kept at $70^{\circ} \mathrm{C}$ for 4 hours didn't show any change in the spectra or in LC-MS traces, when the dye was not illuminated. Thus, for the transformation in ethanol, both oxygen and light are needed. Interestingly, LC-MS experiments revealed that the transformation in $n$-propanol results in a new compound with a mass 14 amu higher than the product formed in ethanol. This leads to the conclusion that the alcohols are incorporated in the dye during the reaction. The absolute values of the mass of the newly formed compounds is 2 amu less than the sum of the mass of compound 1 and one of the alcohols which points to a photo-oxidation reaction.

With the aid of preparative LC-MS the newly formed compounds were isolated. Figure 3-2 shows the photoluminescence spectra in ethyl acetate of the starting compound $\mathbf{1}$ and the isolated product obtained after the photo-oxidation reaction in ethanol. The excitation spectra exhibited the same shape as the absorption spectra in ethyl acetate. The compound obtained in n-propanol exhibits the same spectra as the compound obtained in ethanol. The red color of the new compounds can be attributed to a substitution of one of the hydrogens in compound 1 by an ethoxy or propoxy group originating from ethanol or $n$-propanol, respectively. Reaction occurred with the oxygen atom of the alcohol as concluded from the ${ }^{1} \mathrm{H}-\mathrm{NMR}$ spectra of the product of the reaction product with ethanol that exhibit signals at $4.68 \mathrm{ppm}$ (quartet, $\mathrm{J}=6.9 \mathrm{~Hz}$ ) and $1.77 \mathrm{ppm}$ (triplet, $\mathrm{J}=6.9 \mathrm{~Hz}$ ) and of the product with $\mathrm{n}$ propanol at $4.58 \mathrm{ppm}$ (triplet, $\mathrm{J}=6.4 \mathrm{~Hz}$ ), $2.17 \mathrm{ppm}$ (multiplet) and $0.88 \mathrm{ppm}$ (triplet, $\mathrm{J}=6.8 \mathrm{~Hz}$ ).

The color change observed by the reaction with the alcohols point to a reaction of the alcohol with the perylene moiety. Various derivatives of $\mathbf{1}$ are known with $\mathbf{H}^{\mathbf{b}}$ (see Figure 3-3) substituted by oxygen, that are red, and exhibit absorption peaks around $550 \mathrm{~nm}[17,18]$. Thus, structure $\mathbf{2 a}$ is an obvious candidate as reaction product.

Further ${ }^{1} \mathrm{H}$-NMR analysis of the photo-oxidation product with ethanol reveals that the two characteristic doublets of $\mathbf{H}^{\mathbf{a}}$ and $\mathbf{H}^{\mathbf{b}}$ of the starting product (see Figure 3-3) are split into 6 doublets and one singlet (see horizontal trace of Figure 3-4). This spectral change can be explained by the substitution of one of the protons $\mathbf{H}^{\mathrm{a}}$ or $\mathbf{H}^{\mathrm{b}}$ by an ethanolate group and the concomitant loss of the four-fold symmetry of the starting product. The singlet can be attributed to $\mathbf{H}^{\mathbf{c}}$ or $\mathbf{H}^{\mathbf{d}}$ in the case of $\mathbf{2 a}$ or $\mathbf{3} \mathbf{a}$, as possible structures, respectively. To distinguish between structures $\mathbf{2 a}$ and $\mathbf{3 a}$, an NMR 2D C-H 3 bands coupling spectrum was recorded (see Figure 3-4). Coupling of the carbonyl carbons of the imide groups that exhibit signals around 165 ppm is only possible with $\mathbf{H}^{\mathbf{c}}$ ( 3 bands coupling) and not with $\mathbf{H}^{\mathbf{d}}$ (4 bands 


\section{ACCEPTED MANUSCRIPT}

coupling). From the relatively intense cross peak between the proton singlet signal at 8.59 ppm and one of the four carbonyl carbon signals of the imide groups it can be concluded that the reaction product corresponds to structure $2 \mathbf{a}$. The product obtained after irradiation in 1propanol exhibits nearly the same spectral properties in the aromatic region and has therefore structure $\mathbf{2 b}$. The position of the substituent in the perylene ring, namely the carbon atom with $\mathbf{H}^{\mathbf{b}}$ is not completely surprising. The reactivity of these positions in the perylene ring is known to be the highest [19].

Absorption of both compounds $\mathbf{1}$ and $\mathbf{2 a}$, measured with the spectral detector of the LC-MS and the NMR spectra of the crude mixtures reveal a conversion of about $30 \%$, before notable byproducts formation occurs. This is mainly observed as bleaching similar to the bleaching in not reactive solvents such as ethyl acetate. No prove for products with more substitutions by ethanol were found. Probably $\mathbf{2 a}$ exhibits a relative good stability towards photo-oxidation. This points to a possible reparative method to make photochemically derivatives of $2 a$ with selected alcohols instead of ethanol. This will be investigated in a forthcoming study.

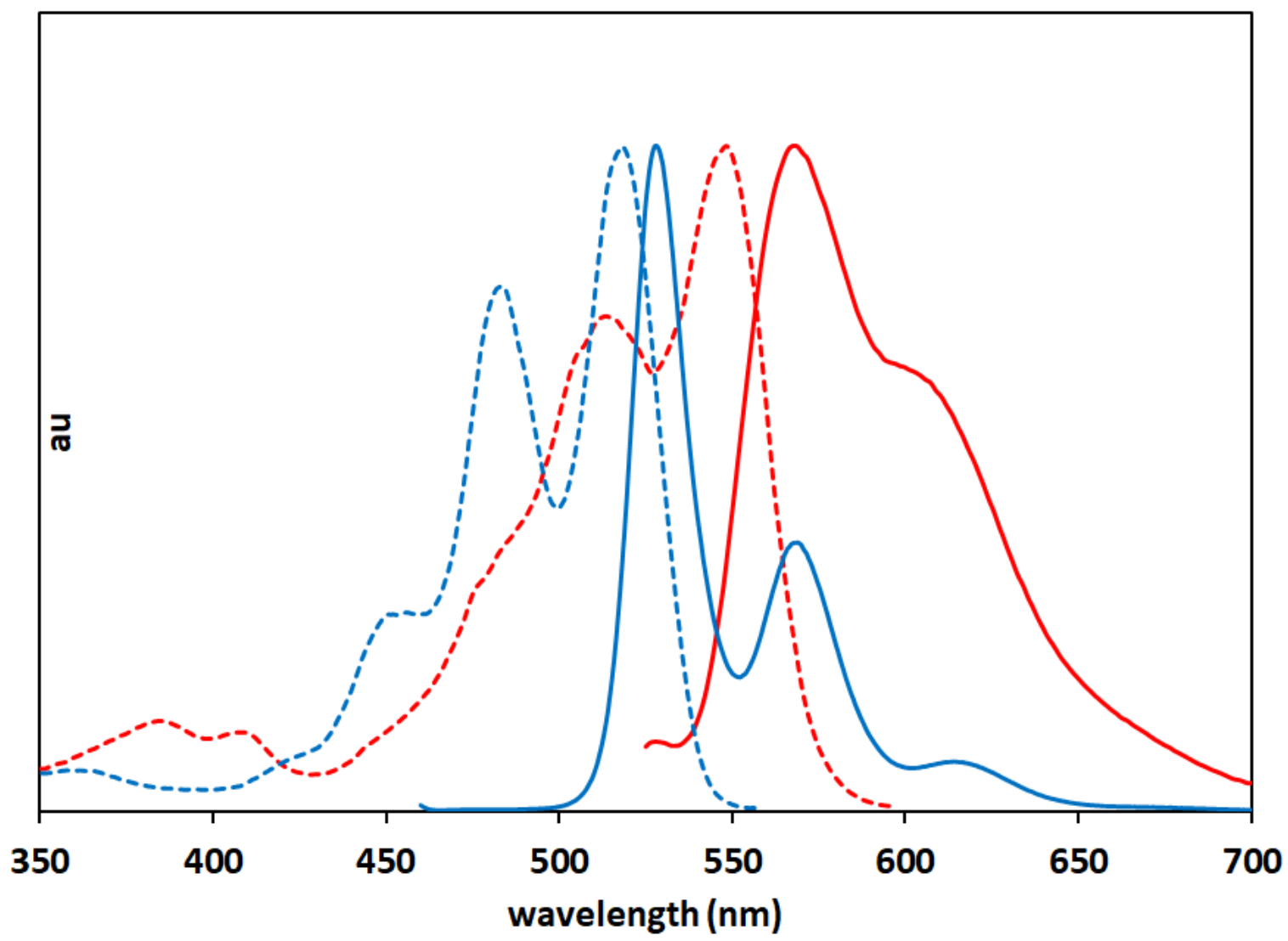

Figure 3-2 Photoluminescence spectra of 1 (blue) and 2a (red) in ethyl acetate. Dotted lines represent excitation spectra and uninterrupted solid lines represent emission spectra. 


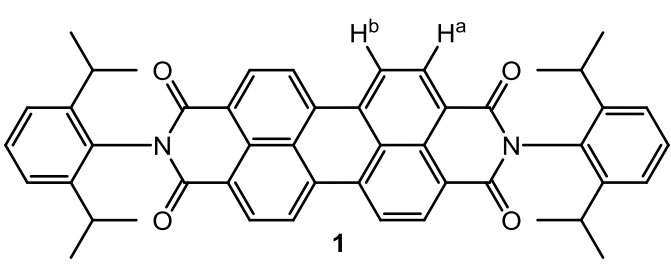

a: $\mathrm{R}=\mathrm{C}_{2} \mathrm{H}_{5}$ b: $\mathbf{R}=\mathrm{C}_{3} \mathrm{H}_{7}$
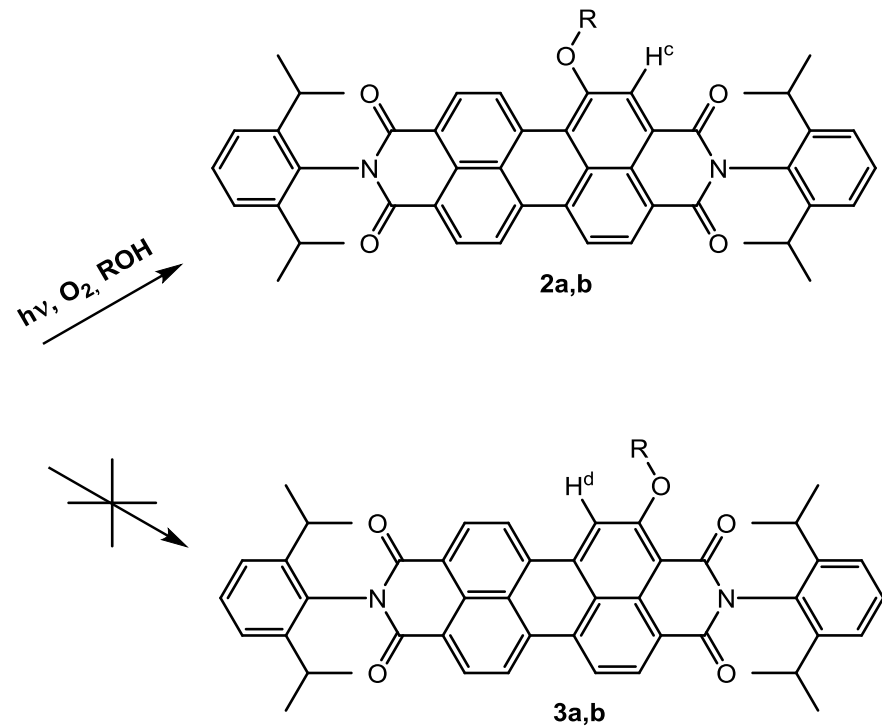

Figure 3-3 Formation of $\mathbf{2 a}$ and $\mathbf{2 b}$ by reaction of $\mathbf{1}$ with ethanol and $n$-propanol, respectively. Compounds $\mathbf{3 a}$ and $\mathbf{3} \mathbf{b}$ are possible isomers of $\mathbf{2 a}$ and $\mathbf{2} \mathbf{b}$, respectively, as discussed in the text.

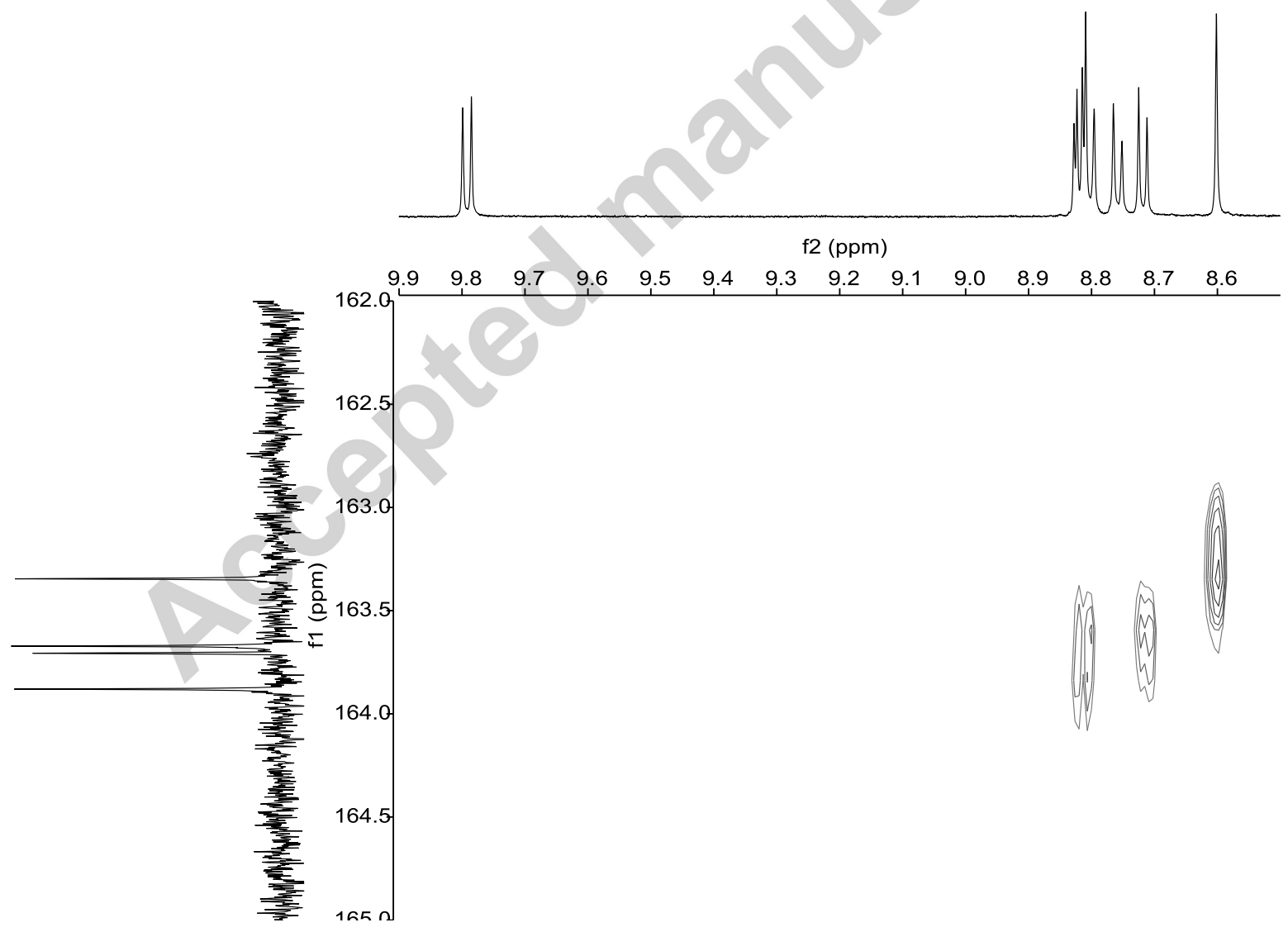

Figure 3-4 Part of the 2D ${ }^{1} \mathrm{H}_{-}{ }^{13} \mathrm{C}$ HMBC spectrum in deuterated chloroform of the reaction product of 1 with ethanol. 


\section{ACCEPTED MANUSCRIPT}

The negative effect of oxygen on the photo-stability of $\mathbf{1}$ and other perylene derivatives in polymeric materials was already shown in former studies. Although, these studies determined kinetics and spectral changes instead of real products as a result of the photodegradation processes it was concluded that the photo-degradation is mainly caused by photo-oxidation processes $[4,8,20]$. The fact that irradiation under aerobic conditions leads to a much faster degradation in mentioned studies, and the fact that reaction with the alcohols occurs only in the presence of oxygen point to a process in which oxidation of $\mathbf{1}$ is the first step to obtain a reactive species that reacts with the alcohol. Such a mechanism is outlined in Figure 3-5.
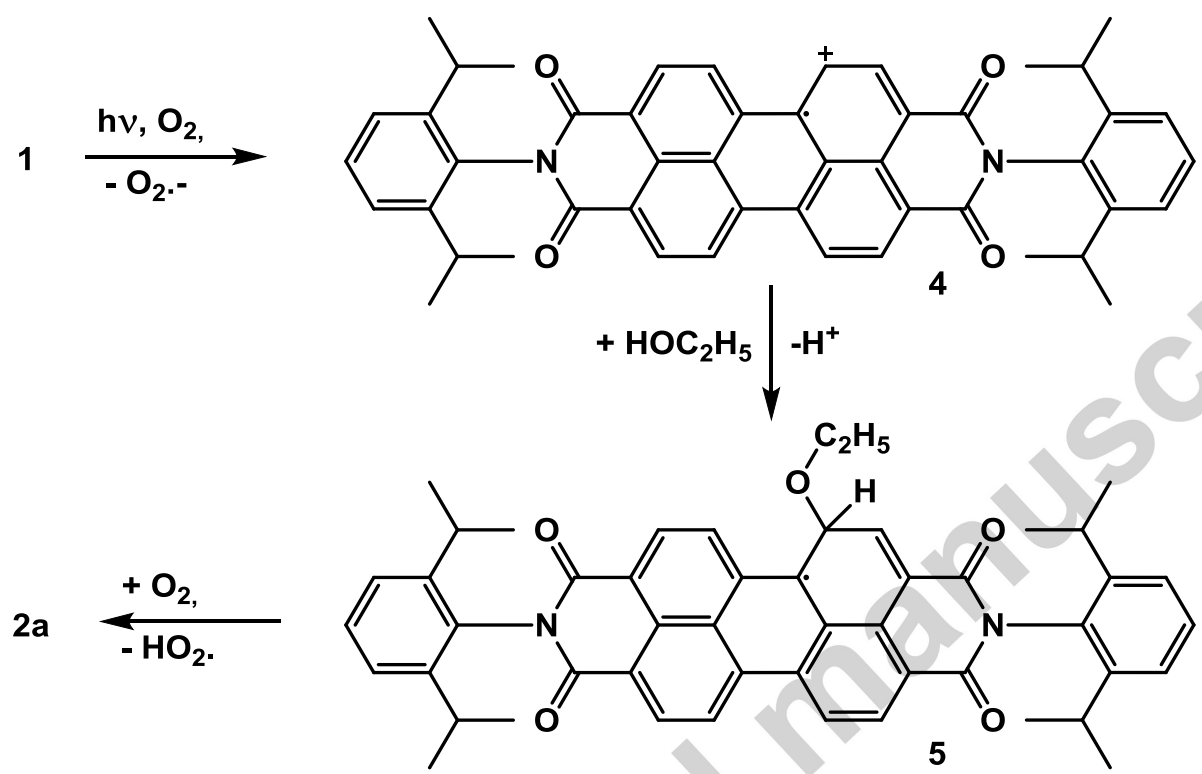

Figure 3-5 Proposed mechanism for the oxidative addition of ethanol to 1 during irradiation with $450 \mathrm{~nm}$ light.

The nature of the oxygen species formed is not clear. Stoichiometrically half an oxygen molecule is consumed in the reaction. Although formation of singlet oxygen can be expected from these type of dyes [9], other studies indicate that in the case of $\mathbf{1}$ oxidation with the formation of superoxide or hydroperoxide is more likely [12]. Photo-ionization of $\mathbf{1}$ has been proposed which leads to fast bleaching in oxygen [21], which may prove the formation of 4 in air. The reaction of radical cation 4 with the nucleophilic ethanol is rather obvious and it is expected that other less nucleophilic solvents such as ethyl acetate and benzene are not incorporated, which explains the absence of formation of perylene derived reaction products similar to $\mathbf{2 a}$. The suggested formation of superoxide $\left(\mathrm{O}_{2}^{-}\right)$in the transformation of 1 into the radical cation 4 (see Figure 3-5) may also lead to reduced 1 (radical anion) [22]. The oxidation as well as reduction of these perylene derivatives are considered as reactions ultimately leading to bleaching of these compound under photo-oxidation conditions 


\section{ACCEPTED MANUSCRIPT}

$[12,22,10]$. However, chemical evidence of the intermediates that play a role in the finally bleached products have not been described. It is very likely that the oxidized intermediate 4 is trapped by the nucleophilic ethanol and that reaction with superoxide doesn't occur under these conditions due to the protonation of superoxide by the solvent or by the proton generated upon reaction of $\mathbf{4}$ with ethanol.

\section{Conclusions.}

The photo bleaching of Lumogen Orange 240(1) was investigated as a model compound for photo luminescent colour conversion in LED by perylene derivatives. This bleaching starts probably with the photo-oxidation to reactive radical cation 4 which ultimately leads to formation of non-colored species in a sequence of reaction. Unfortunately, it was not possible to detect any of the reaction products. In ethanolic solution the reactive intermediate 4 seems to be captured with the formation of ethoxy derivative $2 \mathbf{a}$. The relatively good conversion to $\mathbf{2 a}$ points to a good stability of $\mathbf{2 a}$ towards the photo-oxidation conditions. This might be explained by the fact that this compound is less reactive under these reaction conditions; the ethoxy groups lowers the ionization potential and/or by the fact that after oxidation of $2 \mathbf{a}$ a relatively more stabilized radical cation is formed that restrains further reactions other than reduction by the initially formed superoxide. The use of this photooxidation reaction for preparative purposes and the stability of alkoxy-stabilized derivatives of 1 will be topics of forthcoming studies.

\section{Acknowledgements}

Erica Aussems and Hugo Knobel (all Philips) are thanked for their assistance with the experiments.

\section{References}

1 P. Acuna, S. Leyre, J. Audenaert, Y. Meuret, G. Deconinck and P. Hanselaer, Opt. Express 22 (2014) A1079.

2 J. Lub, S.L.J. Hamon, P.A. van Hal, T.J. Visser, J.M. Jansen and R.A.M. Hikmet, Dyes and Pigments 149 (2018) 662.

3 R.A.M. Hikmet, J.C. Kriege, J.F.M. Cillessen, R.T. Wegh, P.J.C. van der Wel and R. M. A Driessens, WO 2012001645 (2012)

$4 \quad$ J. Lub, , R.A.M. Hikmet and T. van Bommel, US 20150372240 (2015) 
$5 \quad$ J. Lub, R.A.M. Hikmet and D. Veldman, US 20160017219 (2016)

$6 \quad$ J. Lub, R.A.M. Hikmet and D. Veldman, WO 2015062916 (2015)

7 J. Lub, P.A. van Hal and R.A.M. Hikmet, US 2016062657 (2016)

8 L. Luis Cerdán, A. Costela, G. Durán-Sampedro, I. García-Moreno, M. Calle, M. Juan-ySeva, J. de Abajob and G. A. Turnbull, J. Mater. Chem. 22 (2012) 8938

$9 \quad$ N. Tanaka, Barashkov, N.J. Heath and W.N. Sisk, Applied Optics 45 (2006) 3846.

10 M. Haase, C.G. Hübner, F. Nolde, K. Müllen and T. Basche, Phys. Chem. Chem. Phys. 13 (2011) 1776.

11 I. Rengea, C.G. Hübner, A. Renn, H. Langhals and U.P. Wild, Journal of Luminescence 98 (2002) 91.

12 L. Chen, L. A. Lucia, E.R. Gaillard, D.G. Whittenet, H. Icil, and S. Icli, J. Phys. Chem. A. 102 (1998) 9095.

13 A.A. Earp, T. Rawling, Jim B. Franklin and G.B. Smith, Dyes and Pigments 84 (2010) 59.

14 A. Bax and M. F. Summers, Journal of the American Chemical Society 108 (1986) 2093.

15 W. Willker, D. Leibfritz, R. Kerssebaum and W. Bermel, Magnetic Resonance in Chemistry 31 (1993) 287.

16 J. Ruiz-Cabello, G. W. Vuister, C. T. Moonen, P. van Gelderen, J. S. Cohen and P. van Zijl, Journal of Magnetic Resonance 100 (1992) 282.

17 J. Choi, C. Sakong, J. Choi, C. Yoon and J. Kim, Dyes and Pigments 90 (2011) 82.

18 J.Y. Kim, C. Sakong, S. Choi, H. Jang, S.H. Kim, K.S. Chang, M.S. Han, J.S. Lee and J.P. Kim, Dyes and Pigments 131 (2016) 293.

19 C. Huang, S. Barlow and S.R. Marder, J. Org. Chem. 76 (2011) 2386.

20 J. Lub, R. A. M. Hikmet and R. T. Wegh, WO 2012042438 (2012).

21 C. Julien, A. Débarre, D. Nutarelli, A. Richard and P. Tchénio, J. Phys. Chem. B 109 (2005) 23145.

22 W.E. Ford, H. Hiratsuka and P.V. Kamat, J. Phys. Chem. 93 (1989) 6692. 